\title{
Dakwah Kiai Pesisiran: Aktivitas Dakwah Para Kiai di Kabupaten Lamongan
}

\author{
Irzum Farihah* dan Ismanto \\ Sekolah Tinggi Agama Islam Negeri Kudus \\ Email: irzumfarihah@gmail.com
}

\begin{abstract}
$D a^{\prime} w a h$ has a very important position in building a religious understanding of society for the benefit of nowdays and hereafter life. This study aims to describe the activities of da'wah of kiai on the northern coast, especially Blimbing Village, Paciran District, Lamongan City, the majority of people work as fishermen and traders, who have a hard character. Research method This research uses qualitative approach with data collection technique through observation, interview and documentation from 2016 to 2017. Informants in this study are kiai and mad'u (Blimbing Village community). The analysis uses the Miles-Huberman model, in which the instrumental, value, affective, and traditional rationalities of Max Weber are intertwined with one another. Result of research: firstly, da'wah of kiai with bi al qaul of lecture method delivered through pulpit after prayer jamaah subub. Second, the method of manidhah hasanah and mujadalah is done with a personal approach through informal dialogue outside the pulpit. Third, bi al-af'al approach by da'i motivation giving mad'u in everyday life. Fourth, da'wah of al-kitabah by publishing periodic bulletins. From these various da'i approaches, he is able to provide changes in motivation and understanding of religion for coastal community.
\end{abstract}

Keywords : Da'wab; kiai; Coastal Community

\begin{abstract}
ABSTRAK
Dakwah mempunyai posisi yang sangat penting dalam membangun pemahaman beragama masyarakat untuk kepentingan kehidupan duniawi maupun ukhrowi. Riset ini bertujuan untuk melihat aktivitas dakwah para kiai di pesisir utara khususnya Desa Blimbing Kecamatan Paciran Kabupaten Lamongan, mayoritas masyarakat berprofesi sebagai nelayan dan pedagang, yang mempunyai karakter keras. Penelitian ini menggunakan pendekatan kualitatif dengan teknik pengumpulan data melalui observasi, wawancara dan dokumentasi pada tahun 2016-2017. Informan dalam penelitian ini adalah kiai dan mad'u (masyarakat desa Blimbing). Analisis data menggunakan model MilesHuberman. Hasil penelitian menjelaskan bahwa, pertama, dakwah para kiai dengan bi al qaul yakni, pendekatan ceramah disampaikan melalui mimbar setelah jamaah shalat subuh. Kedua, metode manidhah hasanah dan mujadalah dilaksanakan dengan pendekatan secara personal melalui dialog secara informal di luar mimbar. Ketiga, pendekatan bi alaf'al dengan memberikan motivasi para da'i kepada mad'u dalam kehidupan sehari-hari. Keempat, dakwah bi al kitabah dengan menerbitkan bulletin berkala. Dari berbagai pendekatan tersebut, da'i mampu memberikan perubahan dalam motivasi dan pemahaman beragama masyarakat pesisir Kabupaten Lamongan.
\end{abstract}

Kata Kunci : Dakwah, Kiai, Masyarakat Pesisir 


\section{PENDAHULUAN}

Dakwah merupakan media penyebaran rahmat, cinta dan kasih pada sesama manusia bahkan pada sesama makhluk baik makrokosmos maupun mikrokosmos. Allah menurunkan agama Islam merupakan wujud cinta kasih, rabman dan rabimNya, agar kehidupan manusia selamat di dunia dan akhirat. Dakwah merupakan suatu bagian yang pasti ada dalam kehidupan umat Islam. Dalam ajaran agama, dakwah merupakan suatu kewajiban yang dibebankan oleh agama kepada pemeluknya, baik yang sudah menganutnya maupun yang belum. Dakwah juga merupakan seruan atau ajakan kepada keinsafan, atau usaha mengubah satu situasi kepada situasi yang lebih baik dan sempurna, baik terhadap pribadi maupun masyarakat. Perwujudan dakwah bukan sekedar usaha peningkatan pemahaman keagamaan dalam tingkah laku dan pandangan hidup saja, tetapi juga menuju sasaran yang lebih luas. Apalagi untuk saat ini, harus lebih berperan menuju kepada pelaksanaan ajaran Islam secara lebih menyeluruh dalam berbagai aspek kehidupan. Dalam hal ini, sukses dan tidaknya sebuah dakwah bukanlah diukur dari banyaknya mad'u atau gelak tawa maupun tangis para mad'u. Suksesnya dakwah dapat dilihat melalui bekas yang ditinggalkan dalam benak pendengarnya dan kemudian mampu diamalkan melalui tindakan sehari-hari. Menuju tujuan dakwah demikian tidaklah mudah. Perlu adanya usaha yang serius dari para da’i (Shihab, 2014).

Secara sosiologis konsep dakwah dapat dilihat dengan tiga tingkatan: pertama, dakwah hanya bersifat tabligh atau retorika, yakni hanya menyampaikan pesan kepada manusia. Kedua, dakwah berwujud usaha menanamkan nilai-nilai Islam ke tengah-tengah masyarakat. Dakwah dalam pengertian ini sudah bersifat esensial dan membutuhkan pemahaman yang serius dan mendalam, karena pekerjaan menanamkan nilai-nilai (misalnya kejujuran, keadilan dan persaudaraan) membutuhkan dukungan sistem. Dakwah pada tingkatan ini mengharuskan da’i mampu melakukan dialog antar umat dengan beragam budaya dan keyakinan, mampu mendorong terjadinya sosialisasi, implementasi dan akulturasi pewarisan budaya Islam dari satu generasi ke generasi berikutnya. Efektivitas dakwah terukur dari perubahan pemahaman dan perilaku masyarakat yang mampu mengaplikasikannya, dan pada tingkatan ini dakwah sudah harus diimplementasikan pada perubahan sosial. Ketiga, dakwah membentuk masyarakat Islam, dari lingkungan pribadi, keluarga, hingga masyarakat negara, ataupun dunia. Pada tahap ini dakwah membutuhkan sistem jaringan dalam usaha membangun dan mewujudkan sistem Islam dalam semua segi kehidupan (Iqamat al-Ilaby lial bayat al-basyariyah). Pada tingkatan ini seorang da'i memang Islam sebagai tatanan kehidupan masyarakat yang kaffah, dan ketika itu tidak ada sudah tidak ada lagi perbedaan, dan dakwah lebih bersifat rahmatan lil 'alamin (Munir, dkk, 2003).

Wilayah pesisir utara pulau Jawa, tepatnya Lamongan Utara, merupakan salah satu daerah yang sangat kental dengan kegiatan keagamaan dengan 
bimbingan para kiai yang berasal dari daerah setempat. Semangat masyarakat sangat tampak alam menjalankan aktivitas keagamaan. Kegiatan keagamaan dipimpin para kiai dengan berbagai metode demi mempertahankan minat masyarakat untuk selalu mengikuti kegiatan tersebut. Kiai berdakwah tidak hanya dilakukan di dalam masjid dengan metode ceramah yang sifatnya satu arah tanpa memberikan kesempatan bagi mad'u nya untuk bertanya, namun dakwah para kiai juga dilakukan melalui sistem komunikasi dua arah, mad'u diberi kesempatan untuk menyampaikan pertanyaan. Tahun 2010 sebagian kiai mulai menyampaikan dakwah melalui tulisān (bil kitabah).

Beberapa studi berkaitan dengan penelitian tentang dakwah pesisir di antaranya adalah mengenai pembentukan perilaku sosial masyarakat nelayan pesisir oleh Siregar (2013). Metode dakwah yang sudah dilakukan para dai di Kuala Langsa tersebut belum memberikan perubahan perilaku sosial pada masyarakat nelayan (Siregar, 2013). Sedangkan riset Nur Syam (2003) mengkaji tentang konstruksi sosial upacara pada masyarakat pesisir Tuban dan melihat proses islamisasi yang dilakukan Muhammadiyah melalui gerakan pembaharuan keagamaan dan juga Nahdhatul Ulama (NU) proses dakwah kultural di masyarakat pesisir dapat mempertemukan berbagai varian penggolongan sosial-religius dan dapat dijadikan media interaksi sebagai wadah transformasi, legitimasi dan habitualisasi (Syam, 2003).

Begitu pula riset Arifuddin Ismail (2003) tentang pergulatan antara ritual dan modernitas yang menghasilkan dua model interaksi, yaitu interaksi Islam dan tradisi lokal yang dapat mengubah tradisi lokal menjadi tradisi Islam dan tradisi Islam menjadi tradisi lokal atau dikenal dengan Islam lokal (Ismail. 2012). Penelitian Albet Hidayat (2011) tentang Metode dakwah K.H. Mansyur di lingkungan nelayan Desa Kedungmutih Kecamatan Wedung. Metode dakwh dianggap berhasil merubah perilaku beragama masyarakat. Keberhasilan disini tidak terlepas dari usaha K.H. Mansyur dalam mendekati masyarakat dengan melihat kondisi lingkungan sosialnya, tingkat pendidikan dan tingkat pemahaman agamanya.

Dua riset pertama yang dilakukan pada masyarakat pesisir hanya melihat kegiatan dakwah yang menggunakan metode ceramah dalam melakukan perubahan perilaku beragama masyarakat pesisir. Sedangkan riset Nur Syam dan Arifuddin Ismail, lebih melihat kepada ritual-ritual agama yang dilakukan masyarakat pesisir dalam proses dakwah kultural. Sedangkan dalam riset ini, metode yang diterapkan da'i diharapkan mampu dijadikan panutan masyarakat melalui bil lisān, bil bal dan bil af'al.

Riset ini akan mengkaji aktivitas dakwah para pemuka agama di tengah masyarakat pesisir yang beragam dalam profesinya, namun mayoritas mereka mempunyai basic keagamaan yang cukup bagus. Hal ini tidak terlepas dari sejarah walisongo ketika menyebarkan ajaran Islam di pesisir utara Jawa, dan mayoritas ada di wilayah Jawa Timur. Tradisi menyampaikan ajaran Islam melalui para tokoh 
ulama (kiai) menjadi rutinitas masyarakat di Desa Blimbing Kecamatan Paciran Kabupaten Lamongan. Selama ini aktivitas dakwah secara rutin disampaikan kepada khalayak setiap hari setelah shalat Subuh baik di masjid maupun Mushalla. Namun dengan perubahan perilaku yang terjadi di Desa Blimbing, aktivitas dakwah tidak hanya disampaikan secara lisān, tetapi sudah merambah pada tulisān dan juga melalui tindakan yang mampu memotivasi dan mengubah pemahaman atas ajaran agama dari teks menuju konteks. Materi dakwah yang disampaikan para kiai pun cenderung beragam, ada yang selalu berbicara tentang ketauhidan, ada juga yang mengkaitkan antara sejarah rasul dengan konteks kekinian, bahkan sebagian kiai mulai menyampaikan materi dakwah dengan muatan motivasi masyarakat untuk kesejahteraan kehidupan duniawi menuju kebahagiaan kehidupan ukhrawi.

Penelitian ini menggunakan metode kualitatif, yaitu untuk meneliti kondisi objek alamiah di mana peneliti merupakan instrumen kunci. Sedangkan Jenis penelitian yang digunakan adalah studi kasus, dengan tujuan untuk memperoleh diskripsi yang utuh dan mendalam (Miller, 1991) tentang dakwah yang dilakukan para da'i di pesisir Utara, tepatnya di Desa Blimbing Kecamatan Paciran Kabupaten Lamongan. Data penelitian ini terdiri dari primer dan sekunder. Data primer merupakan data yang diperoleh dari informan secara langsung yaitu para da'i dan rekaman materi dakwah. Dalam Webster's New Collegiate Dictionary informan adalah seorang pembicara asli yang berbicara dengan mengulang-ulang kata, frasa, dan kalimat dalam bahasa atau dialeknya sebagai model imitasi dan sumber informasi. Teknik pemgumpulan data yang digunakan adalah observasi dan interview. Sebagaimana yang diungkapkan Ritzer (1992), observasi biasanya digunakan terutama untuk mengamati tingkah laku yang aktual. Analisis penelitian ini menggunakan model Miles-Huberman.

\section{HASIL DAN PEMBAHASAN}

Desa Blimbing letaknya di pesisir Utara laut Jawa yang terletak di Kecamatan Paciran Kabupaten Lamongan, masyarakatnya dikenal sebagai kaum santri dan, mayoritas masyarakat berprofesi sebagai nelayan dan pedagang yang mempunyai karakter keras. Wilayah pesisir utara pulau Jawa, tepatnya Lamongan Utara, merupakan salah satu daerah yang sangat kental dengan kegiatan keagamaan dengan bimbingan para Kiai yang berasal dari daerah setempat. Semangat masyarakat pun sangat tampak, sehingga selalu mengalami perubahan dari waktu ke waktu. Kegiatan keagamaan dilaksanakan para kiai dengan melalui berbagai metode demi mempertahankan minat masyarakat untuk selalu mengikuti kegiatan tersebut. Kiai berdakwah tidak hanya melulu dilakukan di dalam masjid dengan metode ceramah yang sifatnya satu arah saja tanpa memberikan kesempatan bagi mad'u nya untuk bertanya, namun dakwah para kiai juga dilakukan melalui sistem dua arah, jadi diberi kesempatan bagi mad'u untuk menyampaikan pertanyaan. Di 
samping itu, mulai tahun 2010, sebagian kiai menyampaikan dakwah melalui tulisān (bil kitabah).

\section{Konsep Dakwah Masyarakat Pesisir}

Dakwah adalah ajakan manusia kepada hal kebaikan dan melarang pada kemungkaran. Jika dilihat secara etimologis yang berasal dari bahasa arab da'ayad'u-dakwatan yang berarti mengajak, menyeru dan juga memanggil (Yunus, 1980). Sebagaimana dalam QS. Yunus ayat 25: "Allah menyeru (manusia) ke Darussalam (surga), dan menunjuki orang yang dikehendaki-Nya kepada jalan yang lurus (Islam). Kata dakwah di dalam al-Qur'an tertulis sekitar 198 kali yang tersebar dalam 55 surat dan 176 ayat (Syamsuddin, 2016). Menurut Safei (2017) bahwa dakwah diartikan sebagai aktivitas menciptakan perubahan sosial dan pribadi yang didasarkan pada tinkah laku pelaku pembaharuannya. Sedangkan Muhammad Khidr Husain (dalam Syamsuddin, 2016) mendefinisikan dakwah sebagai upaya untuk memotivasi agar orang berbuat baik dan mengikuti petunjuk dan melakukan amar ma'ruf nahi munkar dengan tujuan mendapatkan kesuksesan dan kebahagiaan dunia dan akhirat. Sedangkan tujuan dakwah pada dasarnya ada tiga hal: pertama, tujuan akidah untuk tertanamnya akidah yang mantap bagi setiap manusia. Kedua, tujuan hukum yang dimaksudkan agar terbentuknya umat manusia yang mematuhi hukum yang disyari'atkan oleh Allah Swt. Ketiga, tujuan akhlak untuk terwujudnya pribadi muslim yang berbudi luhur dan berakhlakul karimah.

Sedangkan da'i adalah subyek dakwah yang sangat berpengaruh pada keberhasilan dakwah di tengah masyarakat baik secara lisān, tulisān maupun perbuatan. Sedangkan menurut Nasarudin Latief (dalam Malaikah, 1997) bahwa da'i adalah muslim atau muslimat yagng menjadikan dakwah sebagai suatu amaliah pokok bagi tugas ulama. Da'i juga harus mengetahui cara menyampaikan dakwah tentang Allah azza wajalla, alam semesta, dan kehidupan, serta apa yang dihadirkan dakwah dalam memberikan solusi terhadap problema yang dihadapi manusia, serta metode yang dihadirkannya untuk menjadikan pemikiran dan perilaku manusia tidak salah dan keluar dari ajaran agama tidak melenceng.

Oleh karena itu, seorang da'i hendaknya ditekankan pada pengembangan aspek mental, spiritual, dan emosi serta psyco-motoric manusia untuk mencapai tujuan. Hal ini diharapkan seorang da'i mempunyai kemampuan dalam penguasaan keilmuan dan teknologi, yang diimbangi dengan kekuatan keimanan. Seorang da'i harus mempunyai keimanan dan keyakinan yang kuat dan konsisten, sehingga mampu mempengaruhi perilaku dan kultur hidupnya, di mana dalam tataran aplikasi kehidupan seorang da'i tidak cukup hanya pada taraf keyakinan dan pengakuan saja, namun mampu mencerminkan keyakinan sebagaimana dalam al-Qur'an dan Sunah dengan memiliki sikap tanggungjawab dalam menjalankan profesinya. Seorang da'i harus mencerminkan akhlak yang baik dalam kehidupan sosial masyarakatnya dan memiliki potensi membangun lingkungan sosial yang 
harmonis, sehingga mencerminkan sikap sesuai dengan etika universal yang diikat dengan akidah (Syamsuddin, 2016).

Seorang da'i yang mengajak masyarakat untuk melakukan kebaikan dan menghindari kemungkaran (sebagaimana tujuan dari dakwah) tentunya menginginkan masyarakatnya untuk berubah ke arah yang lebih baik. Metode dakwah yang dilakukan para da'i sendiri beragam, dari ceramah yang sebagaimana sudah dilakukan para pendahulunya dan ada juga yang mulai menyesuaikan dengan kondisi masyarakat nelayan yang jarang di rumah, sehingga lebih bersifat personal dengan menemui da'i di tempat kediaman da'i. Sebagaimana dalam teorinya Max Weber tentang tipe-tipe tindakan sosial yang menjelaskan bahwa bentuk rasionalitas manusia meliputi mean (alat) yang menjadi sasaran utama serta ends (tujuan) yang meliputi aspek kultural (Jones, Bradbury \& Boutillier, 2011), yang dibagi menjadi 4 macam, yaitu: pertama, rasionalitas instrumental; kedua, rasionalitas nilai; ketiga, rasionalitas afektif dan keempat rasionalitas tradisional.

Pada rasionalitas instrumental (instrumental rationality) tindakan manusia yang selalu mempunyai tujuan dan secara rasioanal telah mampu menentukan alat yang akan digunakan untuk mencapai tujuan tersebut. Kemudia disusul rasionalitas nilai (value oriented rationality), rasionalitas masyarakat yang melihat nilai sebagai potensi atau tujuan hidup, meskipun tujuan itu tidak nyata dalam kehidupan. Rasionalitas nilai lebih menekankan bahwa tindakan dikendalikan oleh kesadaran akan keyakinan dan komitmen terhadap tatanan nilai yang luhur. Rasionalitas afektif (affective rationality), tindakan rasionalitas yang berdasarkan pada emosi, rasa sedih, cinta dan yang tidak dapat dijelaskan. Terakhir adalah rasionalitas tradisional (traditional rationality) tindakan manusia berdasarkan pada tradisi yang sudah berjalan secara turun menurun dalam sebuah komunitas (Martono, 2014; Johnson, 1994; dan Maliki, 2012).

Menyampaikan dakwah merupakan tugas mulia, dan tentunya mempunyai harapan apa yang disampaikan akan mudah diterima dan diterapkan dalam kehidupan keseharian. Oleh karenanya perlu beragam metode maupun pendekatan agar dakwah bisa diterima dengan baik. Menurut Tasmara (1997) metode dakwah merupakan pendekatan atau cara-cara yang harus dilakukan seorang da'i untuk mengajak mad'u pada suatu tujuan dengan landasan hikmah (kebijaksanaan) dan kasih sayang. Ada beragam metode dakwah yang dapat digunakan di masyarakat, tentunya harus melihat terlebih dahulu situasi dan kondisi sasaran dakwah. Sebagaimana dijelaskan dalam QS. an-Nahl ayat 125 yaitu: Pertama, metode bi al-hikmah, kata hikmah berasal dari kata "bakama" yang berarti kebijaksanaan (Munawir, 1997). Hikmah dalam konteks dakwah adalah penyampaian ajaran Islam untuk membawa orang kepada kebenaran dengan mempertimbangkan kemampuan dan ketajaman rasional atau kadar akal penerima dakwah (Aripuddin, 2011). Hikmah merupakan pendekatan komunikasi yang dilaksanakan atas dasar persuasif, karena dakwah terfokus pada buman oriented, maka konsekuensi logisnya adalah pengakuan dan penghargaan pada hak-hak 
yang bersifat demokratis, agar fungsi dakwah yang utama bersifat informatif (Amin, 2009). Menyampaikan dakwah di tengah masyarakat pesisir tidaklah mudah, karena kehidupan mereka yang "keras" dapat mempengaruhi cara berperilaku masyarakat. Ketika penyampaian materi penekanannya adalah bi al-hal dari para da'i, baik dari ucapan maupun perilaku. Da'i dituntut untuk mampu menempatkan bahasa yang sesuai dengan apa yang mereka fahami (bahasa kaum).

Kedua, Metode Mauidhob Hasanah, mauidhah adalah uraian yang menyentuh hati yang mengantar kepada kebaikanbagi mad'u atau dengan nasehat yang baik. Menyampaikan materi dakwah dengan menggunakan bahasa yang baik dan mampu mengubah hati, agar nasehat tersebut dapat diterima. Mauidhah hasanah sendiri merupakan penggabungan antara kelembutan ucapak dan keteladanan tindakan pendakwah (Aziz, 2009), hal ini juga yang selalu diterapan oleh Rasulullah sehingga dakwah beliau seringkali berhasil dan mampu menarik simpati para mad'u-nya. Ketiga, metode mujadalah. Al-Mujadalah masdar dari "jadala" yang mempunyai arti berdebat. Dalam berdiskusi (mujadalab) Allah mengingatkan harus dengan ihsan, karena seringkali terjadi di masyarakat dalam perbedaan pendapat, maka diperlukan dialog dan perdebatan (Fatoni, 2004). Hikmah sebagai induk dari metode dakwah juga meliputi pendekatan dakwah melalui debat yang terpuji (aljidal bi allati hiya absan). Pendekatan dakwah ini dilakukan dengan dialog yang berbasis budi pekerti yang luhur, tutur kalam yang lembut, serta mengarah kepada kebenaran dengan disertai argumentasi demonstratif rasonal dan tekstual sekaligus, dengan maksud menolak argument bathil yang dipakai lawan dialog. Debat yang terpuji dalam dakwah tidak memiliki tujuan pada dirinya sendiri. Ia lebih ditujukan sebagai sarana untuk mencapai kebenaran dan petunjuk Allah Swt. Masyarakat yang mempunyai latar belakang agama "abangan", tentunya mempunyai pemahaman agama yang masih minim. Maka hendaknya ketika selesai penyampaikan materi dakwah oleh para da'i, diberikan kesempatan untuk tanya jawab agar tidak terjadi perselisihan faham yang mereka belum mengetahui landasan hukumnya. Hal ini penting sekali, karena selain menambah keilmuan agama bagi masyarakat juga mampu mendekatkan komunikasi antara da'i dan mad'u.

Seorang da'i menjadi panutan para mad'u-nya, oleh karena itu penting sekali seorang da'i memberikan contoh dalam bertutur maupun bertindak dengan baik yang nantinya dijadikan figur seorang pemimpin (panutan dalam agama) yang baik. Ketika sudah mampu mengambil tempat dihati para mad'u, maka akan lebih mudah seorang da'i mengajak ke arah kebaikan. Sebagaimana menurut Sambas dalam Aripuddin (2011), ada empat cara bagi seorang da'i akan dinilai mad'unya: pertama, seorang da'i akan dinilai dari reputasi yang mendahuluinya, termasuk di dalamnya riwayat pendidikan dan perilaku da'i sebelumnya. Kedua, Seorang da’i dinilai juga dari informasi yang diperoleh oleh mad'u dari orang lain, disinilah akan dilihat kredibilitas seorang da'i dihadapan masyarakat teruji. Ketiga, melalui tutur katanya, sebagaimana Ali bin Abi Thalib pernah menyampaikan bahwa lisān 
adalah ukuran seorang manusia (al-lisän mizan al-insan). Jika seorang da'i sering berkata kasar dan rendah, maka kualitasnya sama dengan tuturnya, termasuk jika seorang da'i selalu mempengaruhi mad'u menyampaikan ujaran kebencian kepada kelompok yang berbeda. Keempat, melalui bagaimana da'i menyampaikan pesan dakwahnya, sistematis atau justru membingungkan mad'u.

Ibnu Taimiyah (dalam Suparta dan Hefni, 2015) mengungkapkan bahwa sifat yang harus melekat pada diri seorang da'i adalah harus memiliki ilmu tentang hal yang ma'ruf dan yang munkar dan mampu membedakan antara keduanya, juga harus memiliki ilmu tentang memahami kondisi mad'u. Pentingnya seorang da'i berbekal ilmu yang benar berdasarkan sumber ajaran Islam yaitu al-Qur'an dan assunah dengan memiliki kualitas akademik keislaman yang baik dan tentunya konsistensi antara amal dan ilmunya. Sedangkan Yusuf Qardhawi (1979) mengungkapkan, seorang da'i perlu melengkapi dirinya pada tiga senjata, yaitu senjata iman (silah al-iman), akhlak mulia (al-akblak al-karimab), ilmu pengetahuan dan wawasan. Senjata iman dan akhlak disebut sebagai bekal spiritual, sedangkan ilmu dan wawasan sebagai bekal intelektual. Sedangkan Sayyid Quthub (dalam Ismail, 2011) menambahkan dengan kekuatan perjuangan (quwwat al Jihad) atau yang disebut dengan dakwah pergerakan (dakwah harakab).

Karakteristik masyarakat pesisir sangatlah berbeda dengan masyarakat perkotaan, meskipun di wilayah pesisir saat ini sudah terdapat banyak industri perikanan. Penduduk di wilayah pesisir utara Jawa, khususnya tidak semua bekerja sebagai nelayan, namun mayoritas mereka bekerja di sektor kelautan dan pengolahan hasil laut. Oleh karenanya karakteristik masyarakat pesisir tidaklah mungkin dipisahkan dari kehidupan masyarakat nelayan. Menurut Satria (2015) bahwa karakteristik nelayan menghadapi sumber daya yang hingga saat ini masih bersifat akses terbuka (open access) yang menyebabkan nelayan berpindah-pindah untuk memperoleh hasil maksimal, oleh karenanya resiko yang dihadapi sangatlah tinggi, sehingga menyebabkan nelayan mempunyai karakter yang keras, tegas dan terbuka. Sedangkan menurut Firth (1946) bahwa masyarakat nelayan memiliki kesamaan dengan petani di mana sifat usahanya berskala kecil dengan peralatan dan organisasi pasar yang sederhana, eksploitasi yang sering berkaitan dengan masalah kerja sama, sebagian besar menyandarkan diri pada produksi yang bersifat subsisten, dan memiliki keragaman dalam tingkat dan perilaku ekonominya.

Masyarakat pesisir menurut tidak berbeda dengan masyarakat pedesaan lainnya. Jika dikaitkan dengan tipe solidaritas yang menurut Durkheim dibagi menjadi 2, yaitu solidaritas mekanik dan solidaritas organik. Ciri solidaritas mekanik ditandai dengan masih kuatnya kesadaran kolektif (conscience collective) sebagai basis ikatan sosial (Abercrombie, Hill, \& Turner, 2006), yang dikarenakan homogenitas masyarakat yang belum mengalami division of labour (pembagian kerja). Sedangkan pada solidaritas organik kesadaran kolektifnya melemah hal ini dibarengi dengan pembagian kerja yang tinggi (Jary \& Jary, 1991). Sebagaimana tabel di bawah ini: 
Tabel 1. Solidaritas Mekanik dan Organik

\begin{tabular}{ll}
\hline Solidaritas Mekanik & Solidaritas Organik \\
\hline Pembagian kerja rendah & Pembagian kerja tinggi \\
Kesadaran kolektif kuat & Kesadaran kolektif lemah \\
Hubungan represif dominan & Hukum restitutif dominan \\
Konsensus terhadap pola-pola normatif & Konsensus pada nilai-nilai abstrak dan umum \\
penting & penting \\
Relatif saling ketergantungan rendah & Relatif saling ketergantungan tinggi \\
Individualitas rendah & Individualitas tinggi \\
Bersifat primitive atau pedesaan & Bersifat industrial-perkotaan \\
\hline
\end{tabular}

Sumber: Johnson (1994)

Menurut ajaran Islam, bagaimana kita hidup di dunia ini akan menentukan nasib kita di akhirat nanti, walaupun kehidupan dunia dan akhirat itu sama pentingnya, tetapi penduduk Lamongan Khususnya Desa Blimbing menganggap bahwa kehidupan dunia menjadi kunci menuju kehidupan akhirat. Dengan perkataan lain, mereka percaya bahwa dengan mencapai kebaikan di dunia, mereka bisa mencapai kebahagiaan di akhirat kelak. Apabila seseorang ingin memperoleh kebaikan di dua kehidupan tersebut, maka kita harus menyiapkannya dengan baik dan mempunyai etos dalam bekerja dan beribadah. Hal ini untuk mencapai kedudukan yang lebih tinggi duniawi maupun ukhrawi.

Kegiatan keagamaan sangat kental dan marak, karena banyaknya tokoh agama desa yang selalu memberikan pencerahan pada umatnya. Masyarakat Blimbing yang dikenal taat beribadah baik secara transendental maupun sosial. Salah satunya dapat dilihat dari masjid maupun mushalla yang selalu dipadati para jamaah. Khusus setiap subuh, adanya ceramah yang disampaikan oleh para tokoh yang sudah dijadwalkan pada masing-masing masjid maupun mushalla. Tidak hanya terlaksana pada masjid dengan ideologi tertentu, namun dapat selalu melaksanakan jamaah shalat subuh di masjid maupun mushalla, baik Muhammadiyah maupun NU, hal tersebut menjadi kebiasaan sejak dahulu kala.

Semangat untuk mempelajari agama sangatlah kuat bagi masyarakat Desa Blimbing, hal ini tidak hanya sekedar pemahaman, namun pengaplikasian dalam ibadah sosial pun sangat semarak. Sebagaimana ketika mereka diminta untuk menyumbangkan sebagian hartanya untuk kegiatan keagamaan (pembangunan masjid secara fisik maupun mendatangkan seorang da'i), maka mereka akan dengan suka rela meminta untuk menjadi salah satu donator dalam kegiatan tersebut. Selain itu, berkaitan dengan ibadah sosial juga menjadi kebiasaan masyarakat Blimbing. Seperti halnya pelaksanaan kurban dan santunan kepada kaum dhuafa baik melalui zakat maupun shadaqah. Perilaku beragama masyarakat Blimbing tersebut tidak terlepas dari pencerahan yang diberikan para da'i yang sudah menjadi kemantapan masyarakat dalam menyampaikan substansi-substansi agama di masjid maupun mushalla. 


\section{Metode Dakwah Kiai Pesisir Lamongan}

Berdasarkan hasil penelitian, paling tidak ditemukan tiga metode dakwah yang dilakukan oleh kiai pesisir Lamongan, yaitu dakwah bi al-lisān, dakwah bi al-af'al, dan dakwah bi al-kitabah.

\section{Dakwah bi al-Lisān}

Dakwah bi al-lisān dikenal sebagai dakwah tatap muka (face to face), dalam pembahasan dakwah dikenal dengan model dakwah konvensional. Dakwah bi allisān), dilakukan melalui kata-kata yang lemah lembut dan mudah dipahami oleh jamaah, dan tidak menyakitkan hati mereka (Sukardi, 2014: 138). Dakwah model ini selalu digunakan di setiap tatanan masyarakat, karena dianggap paling efektif khususnya tipe masyarakat pedesaan. Begitu juga dengan masyarakat di Desa Blimbing, dakwah bi al-lisān sudah menjadi rutinitas yang dilaksanakan setiap selesai shalat jamaah subuh dan setelah shalat jamaah tarawih (khusus bulan Ramadhan). Seorang imam subuh di masjid Darussalam mempunyai tanggungjawab memberikan tausiyah selama 30 sampai 60 menit setiap hari. Materi yang disampaikan para da'i pun beragam dari yang membahas aqidah, kajian keislaman, fiqih, tafsir maupun sejarah para Nabi.

Adapun dari para kiai yang aktif, di antaranya: pertama, Ustaz Amin Sakin, yang sering menyampaikan materi tentang kajian keislaman yang berkaitan dengan realitas kekinian, sebagaimana rangkuman yang pernah beliau sampaikan sebagai berikut:

Bahasan tentang kondisi masyarakat Islam di Gaza, Syiria dan lainnya yang sedang mengalami konflik agama, sehingga banyaknya korban dari warga sipil. Oleh karena itu umat Islam yang berada di Indonesia dalam kondisi damai diharapkan membantu dengan cara mendoakan dan membaca qunut nazilah setiap selesai shalat fardhu khususnya di Bulan Muharram (kebetulan materi dakwah ini saat disampaikan pada Bulan Muharram).

Selanjutnya bahasan tentang adab seorang mu'adzin. Saat ini banyaknya para mu'adzin yang tidak memperhatikan makna lafadz adzan, tapi lebih mengutamakan pada lagunya. Seperti pelafalan Allahu Akbar Allahu Akbar, pada pengucapan lafdhul jalalah yang kedua tidak terbaca "Alif” nya, hal ini dinamakan sebagai ilhad fi asmaillah (penyelewengan nama Allah).

Kedua, materi dakwah tentang tafsir sebagaimana yang disampaikan oleh ustaz Moh. Na'im, sebagaimana berikut:

Membahas tentang tafsir pada 3 ayat QS. Ali Imran yang berurutan yaitu 145 tentang syukur, 146 tentang kesabaran/shobirin dan 148 tentang almukhsinin untuk mempertinggi iman seseorang. Di sini bagaimana seorang hamba memperjuangkan untuk memperoleh pedoman hidupnya dengan memohon doa kepada Allah sebagaimana dalam ayat 147. Dalam kehidupan manusia ada yang mementingkan duniawi saja dan ada yang akhirat saja. Dalam agama, ketika ingin mencapai predikat yang dicontohkan 
"ribbiniyyun" maka perlu adanya keseimbangan antara keduanya (duniawi dan ukhrowi), karena untuk mencapai akhirat perlu diusahakan duniawinya dengan sungguh-sungguh (misalnya ingin shadaqoh, haji, zakat maka dibutuhkannya kekayaan). Semuanya itu harus diusahakan dengan cara yang sungguh-sungguh dan penuh kesabaran (Ceramah 30 September 2016).

Bahasan yang lain pada penafsiran QS. Ali Imran ayat 164 tentang karunia Allah yang agung kepada orang mukmin yang dapat dirasakan sampai sekarang. Karunia tersebut yaitu telah mengutus Rasul (dari jenis manusia) untuk membacakan ayat-ayat Allah kepada manusia membedakan mana yang benar dan mana yang salah (mana yang perintah dan mana yang larangan), hal tersebut menyucikan atau membersihkan secara rohaniyah maupun lahiriyah. Rasul juga mengajarkan kepada manusia tentang semangat untuk mencari ilmu (sebagaimana ayat pertama turun "Iqra") karena manusia yang tidak mau menambah dalam pengetahuan (buta aksara) maka akan buta dalam pengetahuan agama juga. Hal tersebut dalam rangka membangun generasi yang lebih berperadaban.

Ketiga, berbeda lagi dengan ustaz Mashudi Zakaria, materi yang disampaikan seringkali yang bersifat dogmatis, sehingga mampu menggerakkan kondisi psikis mad'u. Apa yang disampaikannya selalu dikaitkan dengan reward (ganjaran) yang akan diterima para pelaku atas kebaikan tersebut. Misalnya:

Penafsiran ayat tentang orang-orang kafir tertutup hatinya. Dijelaskan juga ada tanda-tanda bagi orang kafir dan orang baik. Oleh karena itu setiap muslim harus menyiapkan kehidupan ini dengan beribadah dengan menjalankan semua perintah Allah dan Sunnah Rasul juga meninggalkan hal-hal yang dilarang-Nya (maksiat). Hal tersebut untuk menyiapkan diri menghadap sang Khaliqnya (kematian) untuk kehidupan akhirat (ustaz Mashudi Zakaria, 20 Desember 2016).

Materi dakwah yang lain tentang kemuliaan Bulan Dzulhijjah (ustaz Mashudi Zakaria, 2 November 2016).

Dalam satu Hadis disebutkan tentang anjuran untuk melakukan puasa (terutama puasa Arofah). Di bulan ini yang paling besar ganjarannya adalah Qurban dan Haji. Ajaran Qurban sudah ada sejak Nabi Adam dan dilanjutkan masa Nabi Ibrahim. Ada ucapan Rasulullah: "Siapa yang mempunyai rizki banyak tapi tidak mau berqurban sampai mati, maka matinya tidak Islam", "Ganjaran Qurban itu sebanyak bulunya binatang tersebut, setiap bulu terdapat 10 kebaikan dan akan dibangunkan gedunggedung di Syurga, sedangkan binatang Qurbannya akan dijadikan sebagai kendaraan dan dapat menolak keburukan".

Keempat, pesan dakwah yang disampaikan oleh Ustaz Munir, materi lebih kepada meluruskan pengetahuan agama mad'u dengan memberikan alasan atas konsep agama tersebut, misalnya:

Bahasan tentang hukum salam dan pengucapannya yang beragam di kalangan masyarakat. Perdebatan di kalangan ulama berkaitan dengan 
beragamnya pengucapan salam, pada bahasannya juga disebutkan alasan dari para ulama'. Salam yang terjadi saat ini juga sering kali dengan lambaian tangan. Jika salam tetap diucapkan dan disertai lambaian tangan tetap dibolehkan dan tidak salah, yang menjadi masalah jika salam diganti dengan lambaian tangan itu yang tidak diperbolehkan agama (Ceramah Ustaz Munir, 13 Maret 2017).

Pembahasan materi dakwah lainnya yaitu mengenai mengunjungi orang sakit di antaranya disampaikan oleh Ustaz Munir, 13 Maret 2017:

Istilah berkunjung ada empat: Pertama, Tyadah (dijelaskan mulai akar katanya) menjenguk orang sakit. Kedua, ziyarah, menjenguk orang sehat. Ketiga, ziarah kubur, mengunjungi makam (lebih dikenal dengan ziarah kubur) orang terdekat. Keempat, ta'riyah, mengunjungi orang yang mendapatkan musibah kematian (kepaten). Iyadah hukumnya fardhu kifayah. Hal tersebut tidak dapat dipisahkan berkaitan dengan hadis Nabi tentang hak muslim atas muslim lainnya yang ada enam kemudian diuraikan masing-masing.

Penyampaian materi dakwah keempat da'i di atas, jika dilihat muatannya sudah beragam. Sebagian lebih kepada muatan kehidupan ukhrowi saja dengan reward yang akan diperoleh bagi umat yang patuh menjalankannya, sedangkan sebagian yang lainnya sudah mulai menyeimbangkan antara kedua kehidupan baik duniawi maupun ukhrowi. Jika dilihat dari tindakan yang dilakukan oleh para kiai selama berdakwah, mereka mempunyai tujuan dan alat (rasionalitas instrumental) untuk mengajak mad'u ke jalan kebenaran yaitu melaksanakan kehidupan duniawi dengan memperbanyak ilmu pengetahuan agama dan mengaplikasikannya pada kehidupan bermasyarakat, untuk menjadi bekal kepada kehidupan ukhrawi yang lebih baik. Sedangkan rasionalitas afektif seorang da'i di sini dapat dilihat dari materi yang disampaikan mampu menjadikan perasaan mad'u takut jika tidak mematuhi ajaran agama dan juga perasaan senang ketika mendengar ganjaranganjaran yang dijanjikan agama bagi yang melakukan kebaikan.

Sedangkan rasionalitas nilai terdapat pada tindakan da'i tersebut. Setiap apa yang disampaikan kepada mad'u selalu mempunyai landasan, sebagaimana yang ditetapkan Allah dalam al-Qur'an dan disabdakan Nabi dalam al-Hadis. Rasionalitas tradisional di sini bahwa tausiyah para da'i setiap hari di masjid Darussalam setelah shalat jamaah subuh sudah dilaksanakan sejak dahulu kala dan sudah mentradisi di tengah masyarakat pesisir Desa Blimbing.

\section{Dakwah bi al-Afal}

Dakwah yang dilakukan masyarakat Blimbing ini, memang mempunyai keunikan dibandingkan dengan daerah-daerah pada umumnya (khususnya wilayah pedesaan). Para da'i di Desa Blimbing, selain mereka sebagai tokoh ulama yang disegani dan ilmunya selalu dirindukan masyarakat, mereka rata-rata adalah seorang yang berprofesi sebagai pedagang, sehingga untuk menghidupi keluarganya mereka tidak tergantung dari profesinya sebagai seorang ustaz. 
Masyarakat sendiri sangat termotivasi dalam etos bekerja dari ajaran agama yang disampaikan para ustaz dan juga diimbangi dari contoh secara langsung. Aktifitas berdagang pata ustaz secara tidak langsung menjadi contoh bagi para umat (mad'u) yang ada di Desa Blimbing, misalnya dalam etos kerja, penyeimbangan antara urusan duniawi (bekerja) dan pelaksanaan ibadah keseharian. Selain itu, sebagian ustaz juga melakukan kerjasama dengan para nelayan, dengan menanamkan saham dalam bentuk kepemilikan kapal atau mesin para nelayan untuk melakukan aktivitas kerjanya melaut. Dengan demikian, hubungan ustaz dan mad'u lebih dekat dan sering terjadi diskusi masalah keagamaan secara langsung saat melaksanakan hubungan kerja.

\section{Dakwah bi al-Kitabah}

Dakwah di pesisir utara, khususnya Desa Blimbing mengalami perubahan yang diiringi pemahaman masyarakat yang semakin beragam. Oleh karenanya, para da’i selalu menerapkan empat metode dakwah yang dijelaskan dalam Surat an-Nahl ayat 125. Bil hikmah, selalu memahami kondisi masyarakat yang mayoritas berprofesi sebagai nelayan yang tidak selalu dapat mengikuti tausiyah setiap hari, maka kiai/ustaz memberikan waktu luang untuk menanyakan masalah keagamaan di rumah secara pribadi maupun beberapa orang, hal ini dapat dikatakan bagian dari konseling dan mujadalah.

Selain dengan tatap muka, dakwah kiai di Desa Blimbing juga dilakukan melalui kitabah atau tulisan. Dakwah bi al-kitabah sering kali dilakukan pada tipe masyarakat perkotaan, namun tidak demikian dengan masyarakat pesisir Desa Blimbing. Dakwah model bi al-kitabah sudah berjalan sejak 7 tahun silam, pada komunitas daulah yang ada di Dukuh Gowah. Dakwah bi al-kitabah dilakukan dengan pembuatan bulletin mingguan yang disebarkan kepada masyarakat secara gratis. Melalui media tulisan ini minat baca masyarakat pesisir mulai membudaya, baik kalangan remaja maupun dewasa.

Dakwah melalui tulisan (bi al-kitabah) ini bisa melengkapi kegiatan dakwah kiai yang selama ini identik dengan dakwah lisan. Dengan melakukan dakwah melalui lisan dan tulisa tersebut, maka dakwah kiai bisa dianggap sempurna. Dakwah bi al-kitabah ini dalam pandangan Kuswandi (2016) tidak hanya dilakukan kiai melalui tulisan kitab, sebagaimana para ulama zama dahulu, namun juga dilakukan media komunikasi massa, seperti di majalah, bulletin dan lain-lain. Masyarakat di Desa Blimbing melihat bahwa tulisan kiai di bulletin mingguan Daulah sangat menarik karena menggap kiai memiliki kapasitas keilmuan yang baik dalam pembahasan tulisannya di bulletin tersebut.

\section{PENUTUP}

Dakwah sebagai bagian tugas mulia dilaksanakan para da'i di pesisir utara, tepatnya di Desa Blimbing Kecamatan Paciran Kabupaten Lamongan. Para da'i 
selain menyampaikan misi kemanusiaan melalui tausiyah setelah jamaah shalat subuh dengan berbagai pendekatan dan dengan tujuan untuk menjadikan masyarakat mempunyai wawasan keagamaan lebih baik dalam rangka mempersiapkan kehidupan ukhrawi. Pelayanan masyarakarat oleh para da'i tidak hanya bersifat kolektif, namun juga secara individu. Masyarakat selalu diberikan ruang dan waktu oleh para da'i untuk bisa konsultasi keagamaan.

Dakwah kiai pesisiran selalu mengalami perubahan dan perkembangan. Hal ini menyesuaikan dengan kondisi masyarakat yang juga beragam pengetahuan agamanya dan tidak terlepas dari pengaruh profesi masyarakat yang mayoritas sebagai nelayan dan pedagang yang sering melakukan interaksi sosial dengan masyarakat di luar wilayah pesisir utara. Dakwah bi al af'al para da'i di pesisir Desa Blimbing akan lebih mudah difahami dan dijadikan model para mad'u (masyarakat), karena hal tersebut juga mampu menjadi motivasi dalam pengaplikasian ajaran agama.

\section{DAFTAR PUSTAKA}

Abercrombie, N., Hill, S., \& Turner, B. S. (2006). The Penguin Dictionary of Sociology. London: Penguin Books.

Amin, S. M. (2009). Ilmu Dakwah. Jakarta: Amzah.

Aripuddin, A. (2011). Pengembangan Metode Dakwah. Jakarta: Rajawali Pers.

Aziz, A. (2009). Ilmu Dakwah. Jakarta: Prenada Media.

Fatoni, U. (2014). Respon Da’i terhadap Gerakan Jemaat Ahmadiyah Indonesia (JAI) di Tenjowaringin Tasikmalaya, Jurnal Dakwah, Vol. XV, No. 1. 49-65. Diakses dari ejournal.uin-suka.ac.id/dakwah/jurnaldakwah/article/view/ 298.

Hidayat, A. (2011). Metode Dakwah K. H. Mansyur di Lingkungan Nelayan Desa Kedungmutib Kecamatan Wedung Kabupaten Demak. Skripsi, Jurusan Komunikasi dan Penyiaran Islam, IAIN Walisongo, Semarang.

Ismail, A. (2012). Agama Nelayan (Pergumulan Islam dengan Budaya Lokal). Pustaka Pelajar. Yogyakarta.

Ismail, I. \& Hotman, P. (2011). Filsafat Dakwah. Jakarta: Prenada Media.

Jary, D., \& Jary, J. (1991). Collins Dictionary of Sociology. Glasgow: Harper Collins Publishers.

Johnson, D. P. (1994). Teori Sosiologi. Jakarta: Gramedia Pustaka Utama..

Jones, P., Bradbury, L., \& Le Boutillier, S. (2011). Introducing Social Theory. Inggris: Polity Press.

Kuswandi, I. (2017). Efektifitas Dakwah Kiai melalui Majalah (Studi Atas Efek Tulisan Kiai bagi Santriwati di Pondok Pesantren Al-Amien Prenduan). Dirosat : Journal of Islamic Studies 1(2). 225 - 242. https://doi.org/10.28944/dirosat.v1i2.22 
Malaikah, M. (1997). Manhaj Dakwah Yusuf Al-Qordhowi Harmoni antara Kelembutan dan Ketegasan. Jakarta: Pustaka Al Kautsar

Maliki, Z. (2012). Rekontruksi Teori Sosial Modern. Yogyakarta: Gadjah Mada University.

Martono, N. (2014). Sosiologi Perubahan Sosial. Jakarta: Rajawali Pers.

Miles, M. B. \& Huberman, M. (1994). Qualitative data analysis: An expended sourcebook. London: Sage Publications.

Miller, D. C. (1991). Handbook of Research Design and Social Measurement. London: Sage Publications.

Munawir, A. W. (1997). Kamus Al-Munawir Arab-Indonesia, Cet ke-14 . Surabaya: Pustaka Progresif.

Munir, M. dkk. (2003). Metode Dakwah. Jakarta: Kencana Prenada Media Group.. Qardhawi, Y. (1979). Tsaqafat al-Da `iyyah, Beirut: al-Mu'assasat al-Risalat.

Ritzer, G. (1992). Sociology: a Multiple Paradigm Science. Jakarta: Rajawali Pres.

Safei, A. A. (2017). Sosiologi Islam. Bandung: Sembiosa Rekatama Media.

Satria, A. (2015). Pengantar Sosiologi Masyarakat Pesisir. Pustaka Obor. Jakarta.

Shihab, M. Q. (2014). Membumikan Al-Qur'an. Bandung: Mizan.

Siregar, M. (2013). Mendakwahi Orang-Orang yang sudah Percaya: Pembentukan Perilaku Sosial Masyarakat Nelayan Pesisir Kuala Langsa Propinsi Aceh dalam Jurnal Dakwah, 17(1), 133-155.

Sukardi, (2014). Dakwah bil-Lisan dengan Teknik Hiburan di Kota Banda Aceh, Jurnal Ilmiah Islam Futura. Vol 14, No 1. 134-145. https://doi.org/10.22373/jiif.v14i1.84

Suparta, M. \& Hefni, H. (2015). Metode Dakwah. Jakarta: Prenadamedia.

Syam, N. (2003). Tradisi Islam Lokal Pesisiran (Studi Konstruksi Sosial Upacara Pada Masyarakat Pesisir Palang Tuban Jawa Timur). Disertasi, Program Pascasarjana, Universitas Airlangga, Surabaya.

Syamsuddin. (2016). Pengantar Sosiologi Dakwah. Jakarta: Prenada Media.

Tasmara, T. (1997). Komunikasi Dakwah, Jakarta: Gaya Media Pratama.

Yunus, M. (1980). Pedoman Dakwah Islamiyah. Jakarta: Hidakarya Agung. 